\title{
Assessing Information Literacy among Undergraduates: A Discussion of the Literature and the University of California-Berkeley Assessment Experience
}

\section{Patricia Davitt Maughan}

\begin{abstract}
Although national standards for information literacy have been developed and approved by the Association of College and Research Libraries, little is known about the extent to which undergraduates meet these or earlier sets of standards. Since 1994, the Teaching Library at the University of California-Berkeley has conducted an ongoing Survey of Information Literacy Competencies in selected academic departments to measure the "lower-order" information literacy skills of graduating seniors. The most fundamental conclusion that can be drawn from this survey is that students think they know more about accessing information and conducting library research than they are able to demonstrate when put to the test. The University of California-Berkeley library experience is consistent with earlier study findings that students continue to be confused by the elementary conventions for organizing and accessing information.
\end{abstract}

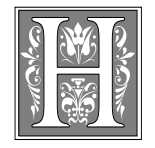
aving crossed the threshold into the twenty-first century, where do academic libraries stand with respect to assessing information literacy among undergraduates? Much has been written on the concept of information literacy during the past twenty-five years. Recommendations and standards for information literacy have been developed and updated nationally by a variety of professional organizations. Yet, little is known about the extent to which undergraduates meet these standards. Moreover, few librarian authors have written on the topic. Inter- estingly, the term information literacy arose from neither the sphere of librarianship nor the halls of higher education but, instead, was first used by Paul Zurkowski, president of the Information Industry Association (IIA).

In a 1974 proposal to the National Commission on Libraries and Information Science, Zurkowski suggested a national goal of achieving information literacy within the following decade. He described information-literate individuals as people "trained in the application of information resources to their work," who "have learned techniques and skills for utilizing

Patricia Davitt Maughan is the User Research Coordinator in the Teaching Library at the University of California-Berkeley; e-mail: pmaughan@library.berkeley.edu. 
the wide range of information tools as well as primary sources in molding information-solutions to their problems." In a subsequent iteration of the concept, IIA dropped its reference to information resources being used exclusively in the workplace and broadened its definition to encompass the use of information tools in fashioning solutions to all sorts of problems. In an article written in 1994, Shirley J. Behrens described additional changes and refinements to the definition of information literacy occurring in the library community throughout the 1970s and 1980 s. $^{2}$ She perceived a paradigm shift among academic librarians by the second half of the 1980s, from one of library literacy to one of information literacy. Previously, Lawrence J. McCrank had observed that "sometimes the term is used as a replacement term for older terms that have simply become passe, like library skills, library use, or bibliographic instruction ... at other times usage implies that this new concept embraces all others as an expansion ... the idea is becoming all encompassing as it matures." ${ }^{3}$ By the end of the decade, Behrens had found that "many user education programs were being replaced by those aiming to achieve information literacy." 4

In 1987, ALA President Margaret Chisholm appointed the ALA Presidential Committee on Information Literacy and charged it with defining information literacy and determining "its importance to student performance, lifelong learning, and active citizenship." ${ }^{\prime 5}$ The committee's final report, issued in January 1989, characterized the information-literate person as someone who is "able to recognize when information is needed," knows what information is needed to address a given problem or issue, and, beyond that, has "the ability to locate, evaluate and use effectively the needed information." Information-literate people were said to be "those who have learned how to learn ... because they know how knowledge is organized, how to find information, and how to use information." In other words, they are "people prepared for lifelong learn- ing." ${ }^{\prime \prime}$ The committee noted that to produce an information-literate citizenry, schools and colleges would need to "integrate the concept of information literacy into their learning programs." ${ }^{\prime 7}$ This underscored the necessity of a new model of learning, one based on information resources and one that is active and integrated, not passive and fragmented. The committee suggested that this new model for learning would further develop critical thinking skills on the part of students and prepare them for a lifetime of learning.

Earlier American education reform reports, including one in 1983 by the U.S. National Commission on Excellence in Education entitled A Nation at Risk: The Imperative for Educational Reform, largely ignored the role of libraries in the educational process. ${ }^{8}$ However, the 1987 report, College: The Undergraduate Experience in America, popularly known as the Boyer Report, gave considerable thought to the role of libraries in addressing the challenges faced by institutions of higher learning. ${ }^{9}$ In its initial release, the Boyer Report noted: "The quality of a college is measured by the resources for learning on the campus and the extent to which students become independent, self-directed learners. And yet we found that today, about one out of every four undergraduates spends no time in the library during a normal week, and sixty-five percent use the library four hours or less each week. The gap between the classroom and the library, reported on almost half a century ago, still exists today."10 In their 1989 book, Information Literacy: Revolution in the Library, Patricia Senn Breivik and E. Gordon Gee emphasized the critical importance of partnerships within colleges and universities in graduating students qualified to be called information literate. The authors mentioned, in particular, the importance of partnerships between the library and classroom instructors, the library and university administrators, and the library and the business community. ${ }^{11}$ With these cornerstones of the information literacy movement in mind, in 1993-1994, the library at the University of California-Berkeley be- 
gan to reorganize the structure and services of the Moffitt Undergraduate Library with the goal of graduating seniors from the university who met the criteria for information literacy.

\section{Teaching Library at the University of California-Berkeley}

The Teaching Library at the University of California-Berkeley was created in 1993 to bridge the gap between the classroom and the library's information resources. Its mission is to ensure that all graduates of the university are thoroughly familiar with the information resources and tools in their respective fields of study, trained in their effective use, and, beyond that, prepared to conduct a search for information resources in any field of inquiry. Placing special emphasis on the humanities and social sciences, library staff design and offer customized in-class presentations aimed at teaching resources and strategies appropriate to particular courses, drop-in workshops on the library's online catalogs and Internetbased resources, and faculty seminars emphasizing electronic tools and resources. Staff at the library have identified and targeted a number of lower-division courses having a library research component that serve as feeder courses through which many students pass to fulfill their general requirements. Moreover, the staff encourage the instructors of these courses to use the course-integrated instructional services offered through the library. In addition, the staff have identified and contacted faculty, graduate student instructors, and other instructors for a number of key upperdivision courses that require library research as part of the course work.

At its inception, the staff, in addition to the position of head of the library, comprised three full-time equivalent program coordinators, a half-time coordinator of user research, and the staff of the Media Resources Center and the Library Graphics Office. The position descriptions for program coordinators and the user research coordinator were new. Candidates to fill the program coordinator positions emerged from existent library staff; they were charged with teaching faculty and students how to use a wide range of information resources. Representing the main instructional arm of the library, program coordinators are expected to collaborate with one another, with selectors throughout the library, with faculty, and with campus student support units to integrate library and information literacy instruction into appropriate points in the university's undergraduate curriculum.

\section{The library hoped to determine the extent to which current graduates possessed a core set of competencies defined by staff as being needed by capable library researchers and information-literate individuals.}

The terms information skills and library instruction involve a range of lower-order competencies, including skills such as using a variety of search systems to retrieve information in various formats, locating information within the library, and differentiating between primary and secondary sources. In contrast, the term information literacy instruction, in addition to the lowerorder skills, includes higher-order abilities such as assessing search results for quality and relevance; evaluating the reliability, validity, authority, and timeliness of retrieved information; and applying new information to the planning and creation of scholarly and professional projects and products. Although the library recognizes the importance of both lower- and higherorder skills and abilities, the staff initially chose to focus on those areas most readily taught and measured within the library world-the lower-order library instruction skills.

Program coordinators provide courseintegrated instruction primarily in the humanities and social sciences. They publicize the library's instructional program, which, in addition to course-integrated instruction, includes catalog instruction and research workshops, faculty seminars, and, in 1993-1994, the Term Paper 
Advisory Service. All of the program coordinators also serve on reference and information service desks but are not responsible for collection development.

The position of half-time user research coordinator also was filled from existent library staff. The user research coordinator designs programs to help the library better understand its users and assists in focusing library public services directly on known user needs. This was particularly important at the time the Teaching Library was created, when the overall library's budget and staffing were shrinking as the range of information resources was expanding. The user research coordinator's role includes identifying user needs and describing, in depth, the levels of information literacy and computer competency possessed by library users.

\section{Measuring Information Competencies as a Means of Marketing the Teaching Library Program}

Why measure student information literacy competencies in the first place? There are many important reasons for doing so, including: to establish a baseline of student skills around which an information literacy program might be built; to assess the effectiveness of particular library instruction sessions or approaches to instruction; to determine the impact of library instruction programs on student information literacy skills and academic success; and to generate data with which to communicate with faculty.

In the spring of 1994, the library administration asked the user research coordinator to undertake an empirical study of the information literacy skills of graduating UC-Berkeley seniors in the departments of political science and sociology. This was part of a larger plan to market the instructional services of the newly formed Teaching Library to campus academic departments. The library hoped to determine the extent to which current graduates possessed a core set of competencies defined by staff as being needed by capable library researchers and infor- mation-literate individuals. If the library determined that graduating seniors did not possess this core set of competencies, it felt this could serve as a compelling argument for promoting a program of ongoing, systematic undergraduate instruction in the identification and use of library and information resources. Moreover, it might serve as an argument in persuading faculty to rely on the services of the library when designing their courses. The political science and sociology departments were selected by library administration as starting points for this marketing effort.

In User Education in Libraries, Nancy J. Fjallbrant and Ian Malley described evaluation as being "concerned with the collection and analysis of information about the input ... [and] ... the variables affecting the educational process, and the end product or output."12 Because no systematic educational process was in place at the Teaching Library in the 1993-1994 academic year (the year of its inception), the user research coordinator focused, instead, on assessment. Fjallbrandt and Malley wrote: "Assessment is concerned with the specific achievement of the individual student ... with regard to pre-specified goals." ${ }^{\prime 3}$ In a 1980 article in Library Trends, Carla J. Stoffle and Judith M. Pryor wrote: "A competency-based program is conceived and planned based on the skills the exit-level student should possess. Competencies are identified with reference to specific roles stated in terms of what the student should know and be able to do." ${ }^{\prime 14}$ They continued: "A competency-based program has three major components: competency identification, criteria level, and assessment. Instruction is also a significant component, but is normally implemented after the three major components. Instruction evolves readily from them and is designed to facilitate the development of the required skills." ${ }^{15}$ Such skills or competencies relate to the accomplishment of specific tasks. In contrast, information literacy is a far more comprehensive concept, encompassing abilities such as critical thinking, synthesis, communication, and 
research methodologies. Although information competencies are easier to assess, the assessment of information literacy outcomes, by contrast, must be a shared responsibility between librarians and faculty.

In 1989, Mary M. Nofsinger wrote: “Articulation of library use/research skills for ... students is a relatively obscure topic in the professional literature ... most instructors simply assume that college students know how to use a library." However, she concluded: "most students enter higher education virtually without any inkling of how to use a library."16 In line with this, Lynn Cameron at James Madison University observed: “The library must clearly define its instructional goals and objectives before it can assess whether they have been achieved."17 Still in its infancy, the Teaching Library set out to do just that. In early 1994, its staff met for a series of discussions to define a core set of competencies that they believed exit-level students at the university should possess. In doing so, the staff referred to both the Maryland Library Association's 1991 "Model Statement of Objectives for Bibliographic Instruction" and the 1987 "Model Statement of Objectives for Academic Bibliographic Instruction" prepared by the ACRL's Bibliographic Instruction Section (ACRL/BIS) and approved by the ACRL Board of Directors and the ALA Standards Committee. ${ }^{18,19}$ Following the library meetings, the user research coordinator drafted two discussion documents for use in promoting the library's instructional program.

The first document, "The Teaching Library-Gateway to Information Literacy," borrowed heavily from the work of Dennis Isbell and Carol Hammond, specifically, the document entitled "Information Literacy Competencies for Students," at Arizona State University West. It provides a succinct working definition of information literacy and a list of conceptual competencies around which the library's instructional program was being built. This document was designed to be shared with department chairs, faculty, and teaching assistants. The library's goals mirror those of Arizona State University West Library's initiative: "to revise and improve library instruction to make it more relevant, market the program to growing numbers of new faculty, and promote the inclusion of an information literacy component in the curriculum development plans of each academic unit." 20

The second discussion document, "Minimum Library Skills for Cal Graduates," focused on competencies described in ACRL/BIS's general objectives three, "How information sources are intellectually accessed by users," and five, "How information sources are physically organized and accessed," outlined in the "Model Statement of Objectives for Academic Bibliographic Instruction." ${ }^{21}$ With the library's statements of core competencies in place, the user research coordinator went about developing an instrument to measure whether graduating seniors at UC-Berkeley possessed these core competencies.

In 1993, Donald Barclay, coordinator of instruction at New Mexico State University Library, called attention to the "recent emphasis on outcomes assessment in higher education," describing interest on the part of "directors, deans, university presidents, and even state legislators" in "what college students are learning." 22 The user research coordinator set out to answer this question with respect to basic student skills in conducting library research, as the first step toward achieving the overarching goal of attaining information literacy. Of course, outcomes assessment combines the measurement of basic skills or competencies with the assessment of higher-order abilities such as evaluation and critical thinking. Stoffle defined competency-based education as "an educational approach which structures learning around competencies defined as fundamental for successful performance." ${ }^{23}$ According to her, the most comprehensive program of competencybased learning in 1980 had been located at the University of Wisconsin-Parkside. Wisconsin's goal for the library skills portion of its collegiate skills program was to develop in students "the ability to use 
the appropriate resources and services of a university library to identify, select and locate materials, both print and non-print, on a variety of subjects." ${ }^{24}$ The library staff initially chose this same approach, focusing on the fundamentals of information competence, those most basic to accessing information resources and upon which the higher-order information literacy skills of analysis, synthesis, and evaluation could be built.

But how could the library measure these fundamentals of information competence? In 1991, Arlene Greer, Les Weston, and Mary Alm observed: "A search of the literature reveals that most library questionnaires geared to an academic population" principally address "issues of user satisfaction." Librarians, they said, were faced with the difficult task of designing a survey instrument that would measure student competencies objectively. ${ }^{25}$ Jill Coupe, too, commented on the lack of a good survey of library skills and suggested that this may well be the reason why librarians have done so little in the way of measuring users' basic library skills. ${ }^{26}$

In developing a survey questionnaire to measure the information literacy levels of graduating UC-Berkeley seniors, the library's user research coordinator relied heavily on the assessment work of Jill Coupe at Johns Hopkins University, which she reported on in her article, "Undergraduate Library Skills: Two Surveys at Johns Hopkins University," and on the Wisconsin Association of Academic Librarians' Education and Library Use Committee's Test of Minimum Library Use Skills, developed nearly a decade earlier. ${ }^{27}$

In the spring of 1994, the Teaching Library developed a self-administered mail questionnaire consisting of thirty-six multiple-choice questions. The first three questions were designed to collect information about the respondents themselves; the remaining questions were designed to test the respondents' mastery of basic library research skills and knowledge of the UCBerkeley library system. The questionnaire was pretested on selected groups of un- dergraduates. A revision of the survey was mailed for the first time in the spring of 1994 to all graduating seniors in the political science and sociology departments. It was administered a second time to all graduating seniors in the history, history of art, and philosophy departments in the spring of 1995. A third survey was conducted in the spring of 1999, again involving all graduating seniors in history, political science, and sociology. The results of those surveys follow.

\section{Results of the Information Literacy Competencies Surveys}

Of the three occasions in which the Information Literacy Survey has been administered thus far, the first cycle resulted in the highest overall return rates. In the spring of 1994, 260 surveys were mailed to graduating seniors in the political science department, of which 185 were completed and returned to the library (a 71\% return rate). One hundred and twentyfive surveys were mailed to sociology graduating seniors, of which seventy were returned (a 56\% return rate). Table 1 reflects the overall return rates from the 1994,1995 , and 1999 surveys. It remains a mystery why the return rates have dropped over time, as the methodology has remained consistent throughout all three of the survey administrations. This methodology included an initial mailing, accompanied by two follow-up mailings to nonrespondents. In all three administrations of the survey, the reward for returning completed surveys also remained the same: a $\$ 10$ gift certificate that could be applied toward the rental of the respondent's cap and gown. Teaching Library Head Ellen Meltzer has observed that the income of UC-Berkeley students' families rose during this time, lessening the appeal of the incentive coupon.

The questionnaire first asked respondents to rate their library knowledge and skills on a four-point scale ranging from "Excellent" to "Pretty poor." Over the five-year span of the study, in all but one group (the 1999 graduating sociology seniors), over half of the respondents (and 


\begin{tabular}{|lcccc|}
\hline \multicolumn{5}{c|}{ TABLE 1 } \\
Survey Return Rates \\
\hline \hline Department & Year & $\begin{array}{c}\text { Number of Surveys } \\
\text { Mailed }\end{array}$ & $\begin{array}{c}\text { Number of Surveys } \\
\text { Returned }\end{array}$ & $\begin{array}{c}\text { Percentage } \\
\text { Returned }\end{array}$ \\
\hline Political Science & 1994 & 260 & 185 & $71 \%$ \\
Sociology & 1994 & 125 & 70 & $56 \%$ \\
History & 1995 & 180 & 110 & $61 \%$ \\
History of Art & 1995 & 26 & 13 & $50 \%$ \\
Philosophy & 1995 & 33 & 14 & $42 \%$ \\
History & 1999 & 218 & 70 & $32 \%$ \\
Political Science & 1999 & 325 & 104 & $32 \%$ \\
Sociology & 1999 & 179 & 70 & $39 \%$ \\
\hline
\end{tabular}

in some cases as high as $70 \%$ to $77 \%$ of the respondents) self-assessed their skills as either "Excellent" or "Pretty good." In no case during the five-year span of the study did more than 14 percent of the graduating seniors studied self-rank their skills as "Pretty poor."

The library's user research coordinator compared students' self-assessments of competency with their actual scores on the questions designed to measure their library and information research skills. In the latter case, anywhere from 35.5 percent to 81 percent of the respondents actually received poor or failing scores (defined as a score of $65 \%$ or lower) on the survey questions. Clearly, those graduating seniors surveyed held a higher opinion of their library research skills than they were able to demonstrate by their test scores.

In reporting on her evaluation of the Library Education Program at Ohio State University, Virginia Tiefel wrote: "students generally fail to realize the substantial differences between school/public and academic libraries and therefore overestimate the extent of their knowledge of the latter. ${ }^{28}$ In a survey conducted at the University of Northern Colorado, Greer, Weston, and Alm tested the hypothesis that both skill and confidence levels increase among college students as a result of cumulative exposure to the library. They found that "self-assessed excellent or good library skills are markedly higher for seniors than for freshmen," yet they found "no dramatic trend of higher proficiency from freshmen to seniors in the test categories." ${ }^{29}$ In her study of library skills among undergraduates at Johns Hopkins University, Coupe found that juniors and seniors were more likely than freshmen to rate their skills as "Excellent" or "Pretty good," but in contrast to the UC-Berkeley results, she found a significant relationship between students' opinions of their library skills and their actual scores. It should be noted, however, that significantly higher percentages of the Johns Hopkins students rated their library skills as "Pretty bad" or "Terrible" (nearly 40\%) than did the UCBerkeley students. The most extreme example of misperceived competency among UC-Berkeley students was the 1995 graduating class in the history of art. None of these students self-assessed their skills as poor, and yet 77 percent received poor or failing scores on the survey's skill questions. A similar phenomenon was discovered among 1999 respondents in political science and sociology. In the first case, only 4 percent rated their skills as "Pretty poor" and yet 71 percent received poor or failing scores. In the latter case, only 7 percent of sociology respondents rated their skills as "Pretty poor," yet 81 percent scored 65 percent or lower on the skills test.

Median overall test scores among the respondents ranged from a low of 54 percent (spring 1999 political science and sociology seniors) to a high of 73 percent (1995 philosophy seniors) over the three surveys. In only three cases, that of history and philosophy students from the 


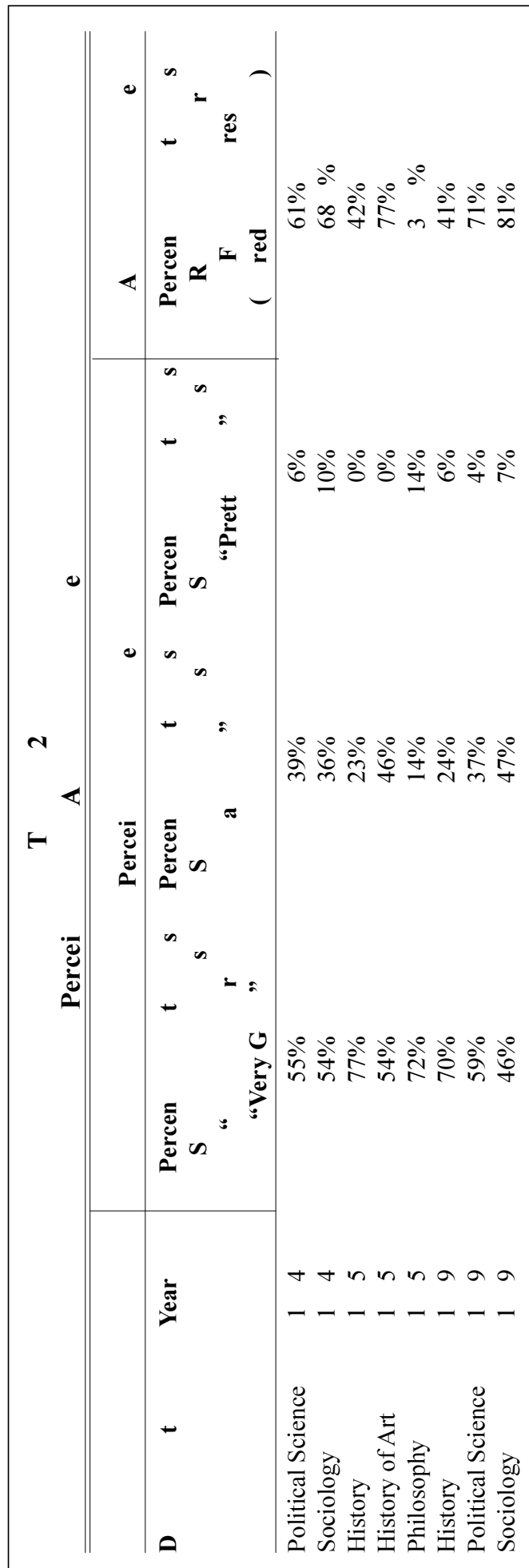

1995 survey and 1999 history seniors, was the median score over 65 percent. In the remaining five groups studied, the median information literacy competency score for graduating seniors was a failing score.

In the course of analyzing the survey results, five basic library skills were identified so as to compare test results among the subgroups surveyed. These were the ability to: (1) read a call number correctly, (2) identify subject headings in a library catalog record, (3) identify a reference to a book, (4) identify references to journal articles, and (5) interpret location information in a catalog serial record. The results of this analysis are reflected in table 4 . In only one case, that of arranging library call numbers in order, were 66 percent or more of the respondents able to demonstrate this basic library skill consistently. In the other basic skills areas, the percentage of students who were able to demonstrate the basic skills being tested ranged from 21 percent to 100 percent.

In her study of library skills among undergraduates at Johns Hopkins University, Coupe had similarly disappointing findings. Although she measured different skills in particular, she found that (1) less than half of the juniors and seniors studied were able to identify what Library of Congress (LC) call numbers were, (2) only 40 percent knew not to search the online catalog to identify journal articles, (3) less than 35 percent could distinguish between a citation to a book and one to a journal article, and (4) only about one quarter of the juniors and seniors knew that the library catalog relied on the use of standardized LC subject headings.

When assessing senior English majors at James Madison University, Cameron found that over half 
did not know how to use the MLA International Bibliography, arguably one of the key resources in that field. She found that psychology majors scored poorly on questions relating to the American Psychological Association's Thesaurus of Psychological Index Terms. A selective review of the UC-Berkeley survey results revealed similarly disappointing findings.

In the 1994 survey of political science seniors, 78 percent were unable to identify the best source in the library for locating congressional publications; 66 percent could not identify what the Public Affairs Information Service is; and 60 percent were unable to identify what the Statistical Abstract of the United States is. However, 65 percent of graduating seniors in political science did correctly identify the appropriate resource for locating an introductory article on Marxism. In 1995, 89 percent of history seniors were unable to identify what America: History and Life is; 56 percent failed to describe Current Contents; and 47 percent were unable to identify what Readers' Guide to Periodical Literature is. Fully 92 percent of the 1995 graduating seniors in the history of art could not identify what Readers' Guide is, and just less than half $(46 \%)$ were unable to describe what Current Contents is and does. Among the 1999 sociology respondents, 69 percent could not identify what Sociofile is. It could be argued that with the current widespread use of electronic indexing and abstracting databases, the need to identify and describe tools such as the Readers' Guide is no longer as important to students as it was when the survey began in 1993-1994. However, students were equally uninformed about the newer electronic resources, such as Current Contents and Sociofile.

Other skill areas that were problematic for the UC-Berkeley graduating seniors surveyed included the ability to: (1) identify the catalog information needed to locate a physical item in the library, (2) find circulation information in a local catalog record, (3) identify the elements needed

\begin{tabular}{lcc|}
\hline \multicolumn{3}{c|}{$\begin{array}{c}\text { TABLE 3 } \\
\text { Median Scores }\end{array}$} \\
\hline \hline Department & Year & Median Score \\
\hline Political Science & 1994 & $64 \%$ \\
Sociology & 1994 & $64 \%$ \\
History & 1995 & $70 \%$ \\
History of Art & 1995 & $61 \%$ \\
Philosophy & 1995 & $73 \%$ \\
History & 1999 & $69 \%$ \\
Political Science & 1999 & $54 \%$ \\
Sociology & 1999 & $54 \%$ \\
\hline
\end{tabular}

in a bibliographic citation, (4) limit search results, (5) recognize which indexes are searchable in the local catalog, and (6) determine when to consult a print versus an electronic indexing source.

In a 1992 article reporting the results of a study of general library skills among undergraduates at Indiana UniversitySouth Bend, Brian R. Schuck found that, on average, the students correctly answered only 34 percent of the multiplechoice questions pertaining to catalog use. He concluded that the results of the general library skills exercises administered to undergraduates revealed a "fair amount of confusion in ... understanding some rather elementary conventions for organizing information-a fair number of study participants encountered problems with such sources/systems as ... the Library of Congress Subject Headings List, the library's own Periodical Holdings List, and the Library of Congress call number system. Reference/instruction librarians cannot assume that students know how to identify a citation in even so well known a source as the Readers' Guide." ${ }^{30}$

Among the departments surveyed more than once at UC-Berkeley, history was the only one where a majority of students' basic library skills improved between the first and the second surveys (see table 5). Interestingly, history is one of the departments on campus where the library's most intensive library instruction efforts have taken place over the past five years. However, it should be under- 
scored that the purpose of the library surveys was not to measure the effectiveness of its instructional program but, rather, to measure the basic library/information literacy competencies or skills of graduating seniors in selected departments. In their 1992 article on performance evaluation, Richard Feinberg and Christine King noted that "only a handful of articles has appeared that describe attempts at measuring program effectiveness." ${ }^{31}$

Overall, the UC-Berkeley surveys seem to indicate that the basic library skill areas where students appear to experience difficulties consistently and where greater attention must be focused in library instruction sessions include the ability to:

- identify and use subject headings;

- correctly identify references to books;

- decipher the location of serials using the information contained in the library catalog's serial records.

Stoffle and Pryor wrote that among the benefits of competency-based learning programs is "the increased potential for structuring of high-quality, relevant library learning experiences." ${ }^{32}$ Over time, instructors in the Teaching Library have used the information from the 1994-1999 surveys and the results of the library's program of pre- and post-testing student research skills within selected course-integrated instructional sessions to identify those skill sets where more intensive instruction and hands-on practice are needed.

Lastly, the surveys included a question on the number of research papers students were required to produce over the course of their undergraduate years (see table 6). Anywhere from 50 percent to 92 percent of undergraduates surveyed were required to write six or more research papers within that time frame. From 21 percent to 46 percent were required to write eleven or more research papers as undergraduates. Possession of even the most basic information literacy skills could well have a profound effect on student success in researching and producing these required papers. Conversely, the absence of such skills could have compro- 
TABLE 5

Changes in Library Skills: History Seniors

\begin{tabular}{lcc} 
Percentage of Seniors Who Could Correctly ... & History 1995 & History 1999 \\
\hline Arrange call numbers in order & $73 \%$ & $83 \%$ \\
Identify a subject heading in a catalog record & & \\
$\quad$ Example 1 & $62 \%$ & $43 \%$ \\
$\quad$ Example 2 & $81 \%$ & $77 \%$ \\
Identify a reference to a book & $37 \%$ & $61 \%$ \\
Identify a reference to a journal article & $71 \%$ & $96 \%$ \\
$\quad$ Example 1 & $65 \%$ & $77 \%$ \\
$\quad$ Example 2 & & \\
Identify location information in a serial record & $87 \%$ & $66 \%$ \\
$\quad$ Example 1 & $54 \%$ & $84 \%$ \\
$\quad$ Example 2 & &
\end{tabular}

mised the quality of their work profoundly and added to the time and effort required to produce their papers.

\section{Recent Developments in the Information Literacy Movement}

Just as things elsewhere in the world at large and in the profession of librarianship seem to be changing and evolving on a continuous basis, so, too, has the notion of information literacy. A number of developments relating to information literacy have occurred since the UC-Berkeley Teaching Library first introduced its Information Literacy Surveys in the spring of 1994.

In 1996-1997, the California Academic and Research Libraries (CARL) Task Force to Recommend Information Literacy Standards to WASC (the Western Association of Schools and Colleges) drafted a statement of principles for in- formation literacy criteria. It also revised the existing WASC standards, which included recommendations on the establishment of institutional information literacy assessment plans. The task force recommended that these plans include: (1) a description of expected learning outcomes; (2) an articulation of "performance indicators for measuring ... specific information competencies"; (3) "a description of the process and methods for collecting data"; and (4) "a statement of how assessment results are incorporated into the information literacy program planning and improvement." ${ }^{\prime 33}$ The task force's draft concepts are now being incorporated more fully into the proposed WASC Integrated Standards for Accreditation of Senior Colleges and Universities in California, Hawaii, and Guam. Currently, WASC is undergoing a rigorous self-evaluation and change in

TABLE 6

Percentage of Undergraduates Writing Research Papers

\begin{tabular}{|lcccc|}
$\begin{array}{c}\text { Department } \\
\text { \& Year }\end{array}$ & $\begin{array}{c}\text { Less than 5 } \\
\text { Research Papers }\end{array}$ & $\begin{array}{c}\text { 6-10 Research } \\
\text { Papers }\end{array}$ & $\begin{array}{c}\text { 11-20 Research } \\
\text { Papers }\end{array}$ & $\begin{array}{c}\text { More than 20 } \\
\text { Research Papers }\end{array}$ \\
\hline Political Science/ & & & & \\
1994 & $17 \%$ & $37 \%$ & $37 \%$ & $9 \%$ \\
Sociology/1994 & $19 \%$ & $43 \%$ & $33 \%$ & $5 \%$ \\
History/1995 & $29 \%$ & $28 \%$ & $29 \%$ & $14 \%$ \\
History of Art/1995 & $8 \%$ & $54 \%$ & $23 \%$ & $15 \%$ \\
Philosophy/1995 & $50 \%$ & $29 \%$ & $7 \%$ & $14 \%$ \\
\hline
\end{tabular}


accrediting processes, developing new models of self-study, and refocusing accreditation on issues of educational effectiveness. The CARL draft Information Literacy Standards have proven instrumental to this effort. In December 1999, CARL past-president Carl Bengston appointed a CARL WASC Accreditation Standards Task Force. This task force has been actively engaged in reviewing and commenting on WASC's Proposed Capacity Standards and Educational Effectiveness Standards, as well as accompanying documents issued by the WASC Senior College Commission.

\section{As indicated in other studies of student library research skills, the UC-Berkeley experience confirms that students continue to be con- fused by the elementary conventions for organizing and accessing information.}

A Web site created by Esther Grassian and Susan E. Clark entitled "Information Literacy Sites," maintained on the ALA Web server, provides links to a dizzying array of megasites, national and local guidelines and reports, programs, tutorials, discussion groups, articles, and organizations and associations interested in information literacy. ${ }^{34}$ The National Forum on Information Literacy maintains its own Web site with links to, among other things, college and university information literacy programs and other information literacy Web sites. ${ }^{35}$

In March 1998, the ALA updated the Final Report of its Presidential Committee on Information Literacy. ${ }^{36}$ More recently, at the 1999 ALA Annual Conference in New Orleans, the ACRL/BIS brought together librarians and educational technologists from across the United States at Think Tank III to present papers on critical information literacy issues. Among the papers presented was one entitled "Justify Our Love: Information Literacy, Student Learning, and the Role of Assessment in Higher Education," by Anne Scrivener Agee and Craig
Gibson, which examined issues relating to the measurement and assessment of information literacy and signaled a rekindling of interest in the area of information literacy assessment. ${ }^{37}$

In January 2000, the ACRL approved the revised draft of "Information Literacy Competency Standards for Higher Education." This document includes five broad standards and twenty-two performance indicators, and its authors recommended: "In addition to assessing all students' basic information literacy skills, faculty and librarians should also work together to develop assessment instruments and strategies in the context of particular disciplines." Further, they strongly suggested that "that assessment methods appropriate to the thinking skills associated with each outcome be identified as an integral part of the institutional implementation plan." ${ }^{38}$ The standards also were endorsed enthusiastically by the board of directors of the American Association of Higher Education (AAHE) in early May 2000. The Middle States Commission on Higher Education has distributed copies of the ACRL standards as resources to their outcomes assessment evaluators assigned to visiting teams for 2000-2001. Moreover, copies were provided to faculty and administrators attending the commission's Outcomes Assessment Conference in March of this year. These latter developments mark an important step in broadening the higher education constituencies into which information literacy standards and assessment planning now may be reintroduced and explored more substantively.

These and other developments in the information literacy movement, which have taken place during the six years since the Teaching Library's Information Literacy Survey was first introduced, undoubtedly will influence the library's thinking about information literacy assessment in the future and how its assessment program grows and evolves. Recent developments are causing the staff to rethink its basic assessment approach. With the assessment experience gained over 
the past six years, the library now has a baseline program from which future assessment initiatives can and will develop.

\section{Conclusion}

The recently adopted "Information Literacy Competency Standards for Higher Education," issued by the ACRL Task Force on Information Literacy Competency Standards, describes five standards for information literacy, twenty-two performance indicators, and a number of outcomes that emanate from these indicators. The outcomes include skills such as determining the availability of needed information; defining an overall plan to acquire information; assessing the quantity, quality, and relevance of search results; evaluating the reliability, validity, accuracy, authority, timeliness, and bias of the information retrieved; recognizing the cultural and other contexts in which information is created; and understanding the impact of these contexts when interpreting the information.

The task force distinguishes between higher-order thinking skills and lowerorder thinking skills. The outcomes just described can be said to fall within the higher-order skills. The information literacy skills measured by the Teaching Library's surveys of graduating seniors fall squarely within the sphere of lowerorder skills.

The most fundamental conclusion that can be drawn from the University of California-Berkeley Teaching Library surveys is that students think they know more about accessing information and conducting library research than they are able to demonstrate when put to the test. Sadly, in five of the eight groups studied between 1994 and 1999, the median score for graduating seniors was a failing score. As indicated in other studies of student library research skills, the UC-Berkeley experience confirms that students continue to be confused by the elementary conventions for organizing and accessing information. Why is this so? There are many possible reasons for this, including the fact that the state of California ranks close to the bottom nationally on funding for school libraries. In 1994, the entire state had only 850 school librarians. ${ }^{39}$ Seven out of eight schools in the state have less than half-time professional library staffing; and although the national ratio of library media specialists to students is $1: 882$, in California the ratio is $1: 5342{ }^{40}$ With this very evident lack of support for school libraries within California, where the majority of UC-Berkeley students reside, is it any wonder that students arrive at the university without information literacy skills? The Information Literacy Surveys focused primarily on the most fundamental and easiest-to-measure information competencies, described as lower-order thinking skills, considered basic to accessing information resources. It is upon these skills that the higher-order information literacy skills of analysis, synthesis, and evaluation are built.

The ACRL task force has recommends that librarians, faculty, and others work collaboratively to develop assessment strategies and instruments. Further, it suggests that this activity can be useful in planning systematic and comprehensive information literacy programs. Finally, it strongly suggests that assessment methods appropriate to the skills associated with each of the outcomes described in the report be identified as an integral part of every institution's implementation plan. These are praiseworthy, yet ambitious, goals that reach well beyond the walls of the library and will require vigorous participation on the part of faculty to achieve. They will call for far more comprehensive programs of assessment to be carried out, again, not just by librarians, but by faculty and other academic personnel on the campus as well.

On the UC-Berkeley campus, initial efforts to assess information literacy skills of undergraduates have been conducted on a periodic and special project basis by a half-time user research coordinator currently employed in the Teaching Library. If the campus and the library decide to adhere to the recommendations of the ACRL Task Force on Information Literacy 
Competency Standards, a far more extensive program involving greater numbers-and a far wider range---of assessors will be required. Patricia Iannuzzi, chair of the task force, wrote: "Information literacy incorporates conceptual, technical, and critical thinking skills. Information literacy is much more than library instruction, and requires an institutional involvement that extends far beyond the library." ${ }^{\prime 41}$ Faculty, in addition to library staff, will be required to take ownership for the development of authentic and course-embedded methods of assessment, including the creation of course assignments that require students to demonstrate mastery of the higher-order abilities outlined and described in the ACRL Information Literacy Competency Standards for Higher Education. Whereas, Iannuzzi wrote: "Information literacy assessment within the library includes measures that can be conducted by the library independently because it has control over the process and can generate and analyze data." ${ }^{42}$ She nonetheless concludes: "if we want to ensure that those skills are applied within other courses, that there is meaningful transfer to other learning environments, and that ultimately the quality of the student's work is improved, the assessment methodology [must move] beyond library control into collaborative efforts with the teaching faculty." ${ }^{\prime 3}$ Developing this thought even further, Iannuzzi wrote: "Strategies for campuswide assessment of information literacy extend far beyond coordination between the reference librarian and the individual faculty members, and beyond the library instruction coordinator talking to department chairs. Strategies at this level require a library culture for information literacy strong enough to influence a campus culture, and this begins with the senior administrators at our libraries and on our campuses. ${ }^{\prime 44}$ Clearly, greater institutional commitment will be necessary to achieve these noteworthy goals.

The results of the UC-Berkeley Teaching Library's Information Literacy Assessment Surveys may or may not represent a microcosm of what is happening elsewhere in the nation with respect to undergraduate information literacy skills. To better understand student information literacy skills nationwide, more systematic and widespread assessment will need to be conducted and the results of these efforts will need to be shared-from library to library and from institution to institution. So, too, the results of the individual library's efforts in information literacy assessment will need to be shared with respective campus faculty and administration if information literacy is ever to become truly a part of each college or university's institutional assessment program.

\section{Notes}

1. Paul G. Zurkowski, The Information Service Environment Relationships and Priorities (Washington D.C.: National Commission on Libraries and Information Science, 1974) 6. ERIC ED 100391.

2. Shirley J. Behrens, "A Conceptual Analysis and Historical Overview of Information Literacy," College E Research Libraries 55 (July 1994): 310.

3. Lawrence J. McCrank, "Academic Programs for Information Literacy: Theory and Structure," RQ 31 (summer 1992): 486.

4. Behrens, "A Conceptual Analysis and Historical Overview of Information Literacy," 313.

5. American Library Association Presidential Committee on Information Literacy, Final Report (Chicago: ALA, 1989), 15.

6. Ibid., 1.

7. Ibid.

8. U.S. National Commission on Excellence in Education, A Nation at Risk: The Imperative for Educational Reform (Washington, D.C.: The Commission, 1983). 1987).

9. Ernest L. Boyer, College: The Undergraduate Experience in America (New York: Harper \& Row,

10. "Prologue and Major Recommendations of Carnegie Foundation's Report on Colleges," Chronicle of Higher Education 33 (Nov. 5, 1986): 10-11.

11. Patricia Senn Breivik and E. Gordon Gee, Information Literacy: Revolution in the Library (New 
York: Macmillan, 1989).

12. Nancy J. Fjallbrant and Ian Malley, User Education in Libraries, $2^{\text {nd }}$ ed. (London: Clive Bingley Limited, 1984), 94

13. Ibid., 96.

14. Carla J. Stoffle and Judith M. Pryor, "Competency-based Education and Library Instruction," Library Trends 29 (summer 1980): 58.

15. Ibid., 58.

16. Mary M. Nofsinger, "Library Use Skills for College-bound High School Students: A Survey," Reference Librarian 24 (1989): 37.

17. Lynn Cameron, "Assessment of Library Skills," in What Is Good Instruction Now? (Ann Arbor, Mich.: Pierian, 1983), 50.

18. Maryland Library Association, Task Force on State Guidelines for Bibliographic Instruction, Model Statement of Objectives for Bibliographic Instruction (n.p.: Maryland Library Association, Academic and Research Libraries Division and Bibliographic Instruction Interest Group, 1991).

19. Association of College and Research Libraries Bibliographic Instruction Section, Task Force on the Model Statement of Objectives, "Model Statement of Objectives for Academic Bibliographic Instruction," College E Research Libraries News 48 (May 1987): 256-61.

20. Dennis Isbell and Carol Hammond, "Information Literacy Competencies," College $\mathcal{E} R e$ search Libraries News 54 (June 1993): 325.

21. ACRL/BIS, "Model Statement of Objectives for Academic Bibliographic Instruction," 259-60.

22. Donald Barclay, "Evaluating Library Instruction: Doing the Best You Can with What You Have," RQ 33 (winter 1993): 196.

23. Stoffle and Pryor, "Competency-based Education and Library Instruction," 55.

24. Ibid., 63.

25. Arlene Greer, Lee Weston, and Mary Alm, “Assessment of Learning Outcomes: A Measure of Progress in Library Literacy," College E Research Libraries 52 (Nov. 1991): 551.

26. Jill Coupe, "Undergraduate Library Skills: Two Surveys at Johns Hopkins University," Research Strategies 11 (fall 1993): 188.

27. Jo Ann Carr, ed., Minimum Library Use Skills: Standards, Test, and Bibliography (n.p.: Wisconsin Association of Academic Librarians, Education and Library Use Committee, Oct. 1984). ERIC ED 263-926.

28. Virginia Tiefel, "Evaluating a Library User Education Program: A Decade of Experience," College $\mathcal{E}$ Research Libraries 50 (Mar. 1989): 256.

29. Greer, Weston, and Alm, "Assessment of Learning Outcomes," 552-53.

30. Brian R. Schuck, "Assessing a Library Instruction Program," Research Strategies 10 (fall 1992): 159-60.

31. Richard Feinberg and Christine King, "Short Term Library Skill Competencies: Arguing for the Achievable," College \& Research Libraries 49 (Jan. 1988): 25.

32. Stoffle and Pryor, "Competency-based Education and Library Instruction," 64.

33. CARL Task Force to Recommend Information Literacy Standard to WASC, "Draft Recommendations to WASC on the Information Literacy Standard," 29 Sept. 1997. Available online at: http:/ / www.carl-acrl.org/Reports/rectoWASC.html.

34. Esther Grassian and Susan E. Clark, "Information Literacy Sites," College E Research Libraries News 60 (Feb. 1999). Available online at: http:/ / www.ala.org/acrl/resfeb99.html.

35. Dane Ward, "Information Literacy: The Key Web Sites," National Forum on Information Literacy. Available online at: http:/ / www.infolit.org/related_sites/index.html.

36. "A Progress Report on Information Literacy: An Update on the American Library Association Presidential Committee on Information Literacy: Final Report," Mar. 1998. Available online at: http://www.ala.org/acrl/nili/nili.html.

37. Alison Level and M. Kathleen Kern, "Information Literacy and the Technological Transformation of Higher Education: ACRL/IS Think Tank III Discussion to Continue with an Online Forum in October," College E Research Libraries News 60 (Oct. 1999): 751-54.

38. Association of College and Research Libraries, Task Force on Information Literacy Competency Standards, "Information Literacy Competency Standards for Higher Education," Jan. 2000. Available online at: http:/ / www.ala.org/acrl/ilcomstan.html.

39. "Schools: Standards Are Important, But Money Is Vital," Los Angeles Times, 22 May 2000, 6.

40. California Department of Education, "A Statistical Snapshot of California School Libraries." Available online at: http://www.cde.ca.gov/cilbranch/eltdiv/library/statis.html.

41. Patricia Iannuzzi, "We Are Teaching, But Are They Learning: Accountability, Productivity, and Assessment," Journal of Academic Librarianship 25 (July 1999): 304.

42. Ibid.

43. Ibid., 305.

44. Ibid. 